\title{
Heterosis and Combining Ability Studies and Relationship Among Fruit and Seed Characters in Peanut ${ }^{1}$
}

\author{
S. L. Dwivedi*, K. Thendapani and S. N. Nigam ${ }^{2}$
}

\begin{abstract}
$F_{1}$ progenies from an $8 \times 8$ full diallel cross were studied for the inheritance of fruit yield and fruit and seed characters which are important in peanut (Arachis hypogaea L.) quality breeding. Substantial genetic variaton was observed for most characters among parents and crosses. Presence of significant heterotic crosses for several characters was an indication of genetic diversity present among the parental lines. Whereas fruit and seed traits were controlled largely by additive genetic effects and fruits/plant and fruit weight/plant by nonadditive genetic effects, for shelling percentage both were equally important. Estimates of general combining ability (gca) for ICGV 86564 was best for various fruit and seed traits. Other genotypes with good gca were ICG 2379 and ICG 3043 for fruit weight/plant and ICGV 87123 for shelling percentage. ICG 4906, ICG 7360, and ICGV 86564 showed significant maternal effects for various traits. Significant maternal interaction effect was evident for more than six traits in six crosses. A positive association among fruit and seed traits, and of fruit weight/plant with fruit number and with fruit/seed length and width should result in progenies with larger fruit/seed size coupled with increased yields.
\end{abstract}

Key Words: Groundnut, maternal effects, diallel, correlation, hybrid vigor.

Desirable traits in India for confectionery peanut (Arachis hypogaea L.) are large elongated seed with tapering ends, pink/tan seed coat, ease in blanching, high sugar content (sucrose), and less than $1 \%$ free fatty acids. Development of high yielding cultivars with these traits is the main objective in the confectionery peanut breeding program at ICRISAT.

Several researchers have studied the genetic variation of quantitative traits including fruit yield, and fruit and seed characters in peanut $(3,8,9,11,12,13,16,17$, 18). However in most of these studies, with the exception of Godoy and Norden (8) and Isleib and Wynne (11), the parental lines did not represent the large genetic variation available for confectionery traits. Study of

${ }^{1}$ International Crops Research Institute for the Semi-Arid Tropics (ICRISAT), ICRISAT Patancheru P. O. 502 324, Andhra Pradesh, India. ICRISAT Journal Article No. 825.

${ }^{2}$ Plant Breeder, former Research Associate, and Principal Groundnut Breeder, ICRISAT, respectively.

*Corresponding Author. the inheritance of fruit and seed traits in crosses involving genotypes with larger variation for confectionery traits was considered desirable to gain a better understanding of the genetic systems controlling inheritance of these traits.

The objectives of present investigation involving germplasm and stable breeding lines with large variation in fruit and seed traits were to (i) characterize the nature and magnitude of gene action controlling fruit yield and fruit and seed characters, (ii) determine the potential of individual parents in producing superior lines, and (iii) determine the genetic relationship among these traits.

\section{Materials and Methods}

Eight genotypes, ICG 4906, ICG 2379, ICG 3043, ICG 6150, ICG 7360, ICGV 86564, ICGV 87123, and ICGV 86857 with large phenotypic variation for fruit and seed traits were used as parents in the study (Table 1). Of these, ICG 4906, ICG 2379, ICG 3043, and ICG 6150 are land races, ICG 7360 a high protein line originally selected from a population of PI 262020 , ICGV 86564 a high yielding breeding line with jumbo pods, ICGV 87123 a recently released cultivar in India, and ICGV 86857 an interspecific tetraploid derivative possessing a high degree of resistance to rust (Puccinia arachidis) and moderate late leafspot (Phaeoisariopsis personata) resistance.

These parents were crossed in a complete diallel generating $56 \mathrm{~F}_{1}$ crosses. The crosses in $F_{1}$ generation and eight parents were grown in Alfisols in a randomized complete block design with three replications at ICRISAT Center in the 1985-86 postrainy season. Plot size was one 4-meter long row with $60 \times 15 \mathrm{~cm}$ inter-and intra-row spacing. Recommended agronomic practices to produce good quality peanuts were followed which includes irrigation, basal dose of $26.2 \mathrm{~kg} \mathrm{P} \mathrm{ha}^{-1}$, application of gypsum $400 \mathrm{~kg} \mathrm{ha}^{-1}$ at the time of full flowering, and protection against insect pests.

Observations on mature fruit weight (fruit weight/plant) and number (fruits/plant) were recorded on ten randomly selected competitive plants/plot after drying to an $8-10 \%$ moisture level. Subsequently, fruits were bulked, and a random sample of 20 fruits were drawn to record fruit weight (g), and fruit length and width ( $\mathrm{mm}$ ). These 20 fruits were further shelled to record seed weight $(\mathrm{g})$, and shelling percentage. Twenty randomly selected seeds were taken to record observations of seed length and width (mm).

Statistical Analysis:

Statistical analysis was performed on plot means. Diallel analysis to estimate various effects and interactions followed the model described by Topham (19) which allows the estimation of maternal effects and their interaction besides estimating general (gca) and specific combining ability (sca) effects. The model is based on method I, model 1 of Griffing (10). The model is fixed and based on a $\mathrm{p}^{2}$ combinations in- 
Table 1. Description of eight peanut genotypes used in diallel crosses.

\begin{tabular}{|c|c|c|c|c|c|c|c|c|c|c|c|c|}
\hline Genotypes & $\begin{array}{c}\text { Other } \\
\text { identity }\end{array}$ & Origin & $\begin{array}{l}\text { Botanical } \\
\text { var. }\end{array}$ & $\begin{array}{c}\text { Frult } \\
\text { woight } \\
\text { [g] }\end{array}$ & $\begin{array}{r}\text { Fruit } \\
\text { Longth } \\
\text { (mm) }\end{array}$ & $\begin{array}{c}\text { Fruit }{ }^{1} \\
\text { width } \\
\text { [min] }\end{array}$ & $\begin{array}{l}\text { Seed } \\
\text { weight } \\
\text { [g] }\end{array}$ & $\begin{array}{l}\text { Seod }{ }^{2} \\
\text { longth } \\
\text { [m] }\end{array}$ & $\begin{array}{l}\text { Seod } \\
\text { width } \\
(\square)\end{array}$ & $\begin{array}{l}\text { Fruttal } \\
\text { plant }\end{array}$ & $\begin{array}{l}\text { Frutt } \\
\text { woight } \\
\text { plant (g) }\end{array}$ & $\begin{array}{c}\text { 8hat ling } \\
{[x]}\end{array}$ \\
\hline IC6 4906 & An Erecta & Sri Lanke & Ver. hypogese & 9 & 338 & 198 & 8 & 178 & 138 & 33 & 91 & 69 \\
\hline ICG 2378 & NC Ac 15989 & Bolivio & Ver. hypogege & 44 & 698 & 301 & 32 & 294 & 220 & 24 & 41 & 73 \\
\hline ICG 3043 & MHOW & Indio & Var. hypogaee & 43 & 767 & 328 & 28 & 370 & 189 & 26 & 39 & 68 \\
\hline ICG 8150 & NC AC 2813 & Argentine & Vor. hypogaeg & 48 & 760 & 335 & 32 & 401 & 207 & 27 & 46 & 87 \\
\hline ICG 7380 & $101 / 66 / 1$ & Z1mobowe & Ver. fastigiate & 33 & 509 & 321 & 22 & 264 & 200 & 98 & 32 & 68 \\
\hline ICEV 86564 & $\begin{array}{c}\text { Ah } 114 \\
x \\
\text { NC Ac } 117\end{array}$ & Ind is & Vor. hypogeas & 57 & 898 & 344 & 41 & 404 & 231 & 15 & 39 & 73 \\
\hline ICGV 87123 & $\begin{array}{l}\text { Robut 39-1- } \\
\text { 18-8-81 }\end{array}$ & Indie & Vor. vulgarie & 32 & 500 & 238 & 23 & 279 & 988 & 28 & 25 & 70 \\
\hline \multirow[t]{3}{*}{ ICOV 86857} & $\begin{array}{l}\text { A. hypogese } \\
\times \text { An cerdenasi1 }\end{array}$ & Indie & Vor. hypogaee & 35 & 880 & 289 & 28 & 300 & 188 & 39 & 38 & 73 \\
\hline & SE $[ \pm]$ & & & $\mathbf{3}$ & 25 & 10 & 3 & 14 & 8 & 19 & 18 & 4 \\
\hline & CV $[x]$ & & & 9.2 & 4.0 & 3.3 & 13.0 & 5.0 & 5.0 & 28.0 & 28.0 & 8.0 \\
\hline
\end{tabular}

1. Recorded on 20 randomly selected mature fruits from the pod bulk of the 10 randomly selected plants/plot.

2. Recorded on $\mathbf{2 0}$ randomly selected sound mature seeds obtained from the pods used for recording fruit traits.

volving 'p' parents and is described as follows:

$$
Y_{i j}=u+g_{i}+g_{j}+m_{i}+s_{i j}+n_{i j}+e_{i j}
$$

where $\mathrm{Y}_{\mathrm{ij}}$ represents the total for the cross between the ith female and the jth male,

$$
\begin{aligned}
\mathrm{u}_{\mathrm{i}} & =\text { general mean, } \\
\mathrm{g}_{\mathrm{i}} \text { and } \mathrm{g}_{\mathrm{j}} & =\text { the ith and the jth parental effects, } \\
\mathrm{m}_{\mathrm{i}} & =\text { the ith maternal effects, } \\
\mathbf{s}_{\mathrm{ij}} & =\text { the genic interaction (sca) between the ith and } \mathrm{jth} \\
& \text { parental effects, } \\
\mathrm{n}_{\mathrm{ij}} & =\text { the interaction between the ith maternal effect } \\
& \text { and the jth paternal effect and, } \\
\mathbf{e}_{\mathrm{ij}} & =\text { an error associated with ith and jth cross. }
\end{aligned}
$$

The parental and maternal effects in this model are the main effects with a condition that $\underset{1}{\stackrel{p}{\Sigma}} \quad g_{1}=0$ and $\underset{1}{\mathrm{p}} \quad \mathrm{m}_{\mathrm{i}}=0$, whereas the other two parameters, $s_{i j}$ and $n_{i,}$, are components of the first order interaction. Further, the condition imposed in this model is that matemal interaction ' $n_{i j}$ ' between the 'ith' maternal parent and the ' $j$ th' paiemal parent and ' $n_{i j}$ ' the interaction between the 'jth' maternal parent and the 'ith' paternal parent is equal in size but in opposite sign to give $n_{i j}+n_{j i}=0$, i.e. $s_{i j}=s_{j i}$ and $\underset{i=1}{p} s_{i j}=\sum_{j=1}^{p} s_{i j}=$ $0=\underset{i=1}{p} \quad n_{i j}=\sum_{j=1}^{p} n_{i j}$.

The various parameters for each variety were estimated as follows:

$$
\begin{aligned}
& u=Y_{1 .} / p^{2} \\
& m_{1}=\left(Y_{1}-Y_{\cdot}\right) / p \\
& g_{1}=\left(Y_{1} .+Y_{1}\right) / 2 p-m_{1} / 2-u \\
& s_{1 j}=\left(Y_{1 j}+Y_{j 1}\right) / 2-g_{1}-g_{j}-m_{1} / 2-m_{j} / 2-u \\
& n_{1 j}=r_{1 j}-s_{1 j}-g_{1}-g_{j}-m_{1}-u
\end{aligned}
$$

The genic interaction effect equals to sca effect as described in Griffing's (10) model. Maternal and parental effects thus estimated are used to derive gca effects to determine the potential of the parent cultivar in a breeding program following the formulae: $g_{i}+m_{i} / 2$, which is the same as the gca effects estimated by Griffing's method (10).
Following Al-Jibouri et al. (1) the genotypic and phenotypic correlations were calculated as follows.

Genotypic ' $r$ ' =

$$
\frac{\sigma \mathrm{P}_{1.2}}{\left(\sigma \mathrm{P}_{1}{ }^{2}\right)\left(\sigma \mathrm{P}_{2}{ }^{2}\right)}
$$

where $\sigma \mathrm{P}_{1,2}$ is the genetic covariance between two traits, $\sigma \mathrm{P}_{1}^{2}$ is the genetic variance of the first trait, and $\sigma \mathrm{P}_{2}{ }^{2}$ is the genetic variance of the second trait; and

Phenotypic ' $r$ ' =

$$
\frac{\sigma \mathrm{Ph}_{1.2}}{\left(\sigma \mathrm{Ph}_{1}{ }^{2}\right)\left(\sigma \mathrm{Ph}_{2}{ }^{2}\right)}
$$

where $\sigma \mathrm{Ph}_{12}$ is the phenotypic covariance between two traits, and $\sigma \mathrm{Ph}_{1}{ }^{2}$ and $\sigma \mathrm{Ph}_{2}{ }^{2}$ are their respective phenotypic variances. Percent heterotic effects were estimated by the mean deviations of $F_{1}$ progenies over the better parent in each cross.

\section{Results and Discussion}

Highly significant differences among the crosses and parents were observed for all nine traits recorded. While the $F_{1}$ progenies differed significantly for all traits, the differences among the parents for fruits/plant, fruit weight/plant, and shelling percentage were not significant.

The estimates of mean squares of main effects and their interactions are presented in Table 2. Both main effects (parental and maternal) and their interaction effects (genic and maternal) were highly significant for fruit weight, fruit length, fruit width, seed length, and seed width. While for seed weight and shelling percentage, genic and maternal interaction effects and parental effects were significant, for fruits/plant and fruit weight/ plant, maternal effects as well as the interactions due to genic and maternal effects were significant. Partitioning of genetic variance into components of gca and sca re- 
Table 2. Analysis of variance of various effects and components of general (gca) and specific (sca) combining ability variance for nine characters in $8 \times 8$ full diallel cross $F_{1}$ progenies in peanut.

\begin{tabular}{|c|c|c|c|c|c|c|c|c|c|c|}
\hline \multirow{2}{*}{ Source of variance } & \multirow{2}{*}{ d.f. } & \multicolumn{9}{|c|}{ Mean equares } \\
\hline & & $\begin{array}{l}\text { Fruit } \\
\text { weight }\end{array}$ & $\begin{array}{l}\text { Fruit } \\
\text { length }\end{array}$ & $\begin{array}{l}\text { Fruit } \\
\text { width }\end{array}$ & $\begin{array}{l}\text { Seod' } \\
\text { weight }\end{array}$ & $\begin{array}{l}\text { Seed }^{2} \\
\text { longth }\end{array}$ & $\begin{array}{l}\text { Seed } \\
\text { width }\end{array}$ & $\begin{array}{l}\text { Fruiter } \\
\text { plant }\end{array}$ & $\begin{array}{c}\text { Fruit weight } \\
\text { plant }\end{array}$ & $\begin{array}{c}\text { Shelling } \\
(\%)\end{array}$ \\
\hline Parental offects (g) & 7 & $1073^{* *}$ & $115869 *$ & $10989 * *$ & $537 * *$ & $25898^{* * *}$ & $3712 *$ & 402 & 1287 & $178 *$ \\
\hline Maternel offect (m) & 7 & $17 * *$ & $1182 * *$ & $412 *$ & 7 & $354^{* * *}$ & $83 * *$ & $463^{* * *}$ & $348^{* 0 *}$ & 10 \\
\hline Maternal interection $\left[n_{1 j}\right]$ & 21 & $15^{* * *}$ & $1802 * 1$ & $178 *$ & $19 * *$ & $221 * *$ & $124^{* *}$ & $155^{* * *}$ & $167^{\circ}$ & $19^{* *}$ \\
\hline Res 1duel & 128 & 4 & 298 & 34 & 3 & 83 & 29 & 45 & 83 & 5 \\
\hline Ver. [gca] & & 67 & 7234 & 685 & 33 & 1583 & 230 & 22 & 75 & 11 \\
\hline Var. (Bca) & & 22 & 1150 & 340 & 18 & 255 & 87 & 168 & 197 & 18 \\
\hline
\end{tabular}

1 and 2 - refer as described in Table 1. "** - significant at 0.05 and 0.01 probability, respectively.

vealed largely additive genetic effects for all six fruit and seed characters. Nonadditive genetic effects were more important in the cases of fruits/plant and fruit weight/ plant. For shelling percentage, both additive and non addditive genetic effects were equally important.

Several studies reported primarily additive genetic effects for fruits/plant, fruit length and width, fruit yield, and shelling percentage $(12,13,16,17,21)$. In other studies both additive and nonadditive genetic effects were reported as controlling the expression of fruit length, fruit and seed weight, fruits number, and fruit yield $(9,15,16)$. From a study of $6 \times 6$ diallel cross based on random model, Wynne et al. (20) reported largely additive variance for fruit length and nonadditive variance for fruit number and fruit yield. Fruit yield was controlled by nonadditive genetic effects in the studies conducted by Sangha and Labana (16). Such reported variation in the inheritance of these traits may be due to differences in the mating system, in the method of analysis (random or fixed model) and/or in the parental material that was used in these studies.

The results obtained from the present study indicated the strong influence of maternal and maternal interaction effects as well as genic effects in the expression of various fruit and seed traits. The traits in the present study represent two separate generations. The expression of fruit traits is controlled by $F_{1}$ genotype and its interaction with the cytoplasm of the female parent of the cross. Whereas the seed traits are governed by $F_{2}$ genotypes and their interactions with the female cytoplasm. However, the expression of $F_{2}$ genotypes of seed is further conditioned by the mother plant ( $F_{1}$ plant) which provides nutrients for the development of embryo (seed).

The parental and maternal effects were estimated for each genotype in order to determine their relative importance (Table 3) along with the gca effects of the genotypes. Significant maternal effects were observed for seven characters in ICG 4906, for five in ICG 7360 , and for four in ICGV 86564. Other genotypes showed maternal effects significant for one or two characters only. Similarly ICG 4906 and ICGV 86564 had significant parental effects for eight and seven traits, respectively, followed by ICG 7360 and ICG 3043 which had parental effects significant for six traits. It is interesting to note that in case of ICG 4906, maternal and parental effects were significant for fruits/plant, fruit weight/ plant, fruit length and width, and seed length and width, followed by ICGV 86564 for fruit weight, fruit width, and seed weight, and ICG 7360 for fruit length, fruit width, and shelling percentage.

Prominant crosses with significant maternal interaction effects were ICG $7360 \times$ ICG 4906 and ICG 6150 $x$ ICGV 86564 for eight characters; ICGV 86564 x ICGV 86857 for seven characters; ICG 4906 x ICG 2379, ICG 4906 x ICG 3043, and ICG 4906 x ICGV 86564 for six characters (Table 4). Presence of significant maternal interaction effects for several characters in many crosses revealed the importance of a combination of a nuclear, cytoplasm, or physiological interplay between the pollen parent and the seed parent as suggested by Topham (19). Earlier report on the significance of non-reciprocal maternal effects were reported for fruit length and fruit weight by Layrisee et al. (12).

Heterosis, expressed as percent increase over the better parent, was significant for most characters in several crosses (Table 5). Significant negative heterotic effects were observed for fruit/seed weight and for fruit/ seed length and width. Additive genetic effects were predominant for these traits. For fruits/plant and fruit weight/plant, several crosses showed significant positive heterotic effects, probably due to predominance of nonadditive genetic effects. Presence of appreciable amount of heterotic effects for most of the characters in these 
Table 3. Parental $(g)$ and maternal $(m)$ effects and general combining ability effects (gca) for nine characters in $8 \times 88$ full diallel cross $F_{1}$ progenies in peanut.

\begin{tabular}{|c|c|c|c|c|c|c|c|c|c|c|}
\hline Genotypo & Effocts & $\begin{array}{l}\text { Fruft } \\
\text { waight }\end{array}$ & $\begin{array}{l}\text { Fruit } \\
\text { Length }\end{array}$ & $\begin{array}{l}\text { Fruit } \\
\text { width }\end{array}$ & $\begin{array}{l}\text { Seed } \\
\text { weight }\end{array}$ & $\begin{array}{l}\text { Seed } \\
\text { leng th }\end{array}$ & $\begin{array}{l}\text { Seed }^{2} \\
\text { width }\end{array}$ & $\begin{array}{l}\text { Fruite/ } \\
\text { plant }\end{array}$ & $\begin{array}{c}\text { Frutt } \\
\text { weight/plant }\end{array}$ & $\begin{array}{l}\text { Shelling } \\
{[x]}\end{array}$ \\
\hline ICG 7360 & $\begin{array}{l}\text { Perental offect } \\
\text { Maternal offect } \\
\text { gce offect }\end{array}$ & $\begin{array}{c}-0.9 \\
3.0^{*} \\
0.5\end{array}$ & $\begin{array}{l}-27.5^{* *} \\
25.1 * * \\
-14.8\end{array}$ & $\begin{array}{l}22.0^{* * *} \\
10.4^{* *} \\
27.2^{* *}\end{array}$ & $\begin{array}{l}-2.0 * \\
0.3 \\
-1.8 * *\end{array}$ & $\begin{array}{c}-9.3^{* *} \\
4.4 \\
-7.1 * *\end{array}$ & $\begin{array}{r}-4.2 \\
4.8 \\
-1.8\end{array}$ & $\begin{array}{l}-0.7 \\
-8.8^{*} \\
-5.1 *\end{array}$ & $\begin{array}{l}-8.0 * \\
2.8 \\
-6.7 *\end{array}$ & $\begin{array}{l}-4.5^{* *} \\
-2.6^{*} \\
-5.0^{* * *}\end{array}$ \\
\hline ICG 4908 & $\begin{array}{l}\text { Perental offect } \\
\text { Maternal offect } \\
\text { gce effect }\end{array}$ & $\begin{array}{l}-18.8^{* *} \\
-3.1^{*} \\
-18.4^{* *}\end{array}$ & $\begin{array}{l}-161.3^{* *} \\
-22.2^{*} \\
-172.3^{* *}\end{array}$ & $\begin{array}{l}-47.8^{* *} \\
-15.2^{* *} \\
-65.4^{* *}\end{array}$ & $\begin{array}{l}-11.4 * * \\
-2.1 \\
-12.4 * *\end{array}$ & $\begin{array}{l}-73.4^{* *} \\
-6.8^{*} \\
-77.8^{* *}\end{array}$ & $\begin{array}{l}-29.7 * * \\
-8.6 * \\
-34.1 * *\end{array}$ & $\begin{array}{r}-4.8^{*} \\
20.1 * * \\
5.4 * *\end{array}$ & $\begin{array}{l}-23.8 * * \\
10.1 * \\
-16.7 *\end{array}$ & $\begin{array}{l}0.6 \\
0.0 \\
0.6\end{array}$ \\
\hline ICG 2378 & $\begin{array}{l}\text { Perentel offect } \\
\text { Maternel offect } \\
\text { gce offect }\end{array}$ & $\begin{array}{l}5.1^{* *} \\
0.6 \\
5.4^{* *}\end{array}$ & $\begin{array}{l}-\quad 3.8 \\
-\quad 4.8 \\
-\quad 6.4\end{array}$ & $\begin{array}{r}90.8^{* * *} \\
-7.8^{* *} \\
8.8^{* * *}\end{array}$ & $\begin{array}{l}4.2^{* *} \\
0.9 \\
4.6^{* * *}\end{array}$ & $\begin{array}{l}-2.7 \\
-4.9 \\
-5.2^{* *}\end{array}$ & $\begin{array}{c}10.8 * * \\
5.1 \\
13.4^{* *}\end{array}$ & $\begin{array}{r}2.8 \\
-5.2 \\
0.3\end{array}$ & $\begin{array}{c}9.5^{*} \\
-0.8 \\
9.2^{* * *}\end{array}$ & $\begin{array}{l}1.80 \\
0.7 \\
2.2^{* 4}\end{array}$ \\
\hline ICG 3043 & $\begin{array}{l}\text { Parentel offect } \\
\text { Maternal offect } \\
\text { gce offect }\end{array}$ & $\begin{array}{l}1.7^{*} \\
-0.1 \\
1.6^{* *}\end{array}$ & $\begin{array}{l}52.9^{* *} \\
18.8^{*} \\
62.3^{* *}\end{array}$ & $\begin{array}{c}13.4^{* *} \\
-2.4 \\
12.2^{* *}\end{array}$ & $\begin{array}{r}0.5 \\
-0.1 \\
0.5\end{array}$ & $\begin{array}{l}15.7 * * \\
17.3^{* *} \\
24.3^{* *}\end{array}$ & $\begin{array}{l}-1.8 \\
-2.7 \\
-3.2 *\end{array}$ & $\begin{aligned} & 5.7 * \\
- & 8.7 \\
& 2.4\end{aligned}$ & $\begin{array}{c}12.3^{* *} \\
-8.4 \\
8.1 * *\end{array}$ & $\begin{array}{l}-1.4 \\
-0.6 \\
-1.7\end{array}$ \\
\hline ICG 6150 & $\begin{array}{l}\text { Parental offect } \\
\text { Maternal offect } \\
\text { gce offect }\end{array}$ & $\begin{aligned} & 3.2^{* *} \\
&- 1.23 \\
& 2.5^{* *}\end{aligned}$ & $\begin{array}{c}71.7 * * \\
-\quad 6.20 \\
68.5^{* *}\end{array}$ & $\begin{array}{c}13.9^{* *} \\
-2.8 \\
12.6^{* *}\end{array}$ & $\begin{array}{r}1.4 \\
-1.3 \\
0.7\end{array}$ & $\begin{array}{c}41.6^{* *} \\
-0.7 \\
41.3^{* *}\end{array}$ & $\begin{array}{r}1.2 \\
-0.8 \\
0.8\end{array}$ & $\begin{array}{c}3.8 \\
-11.8 * * \\
-2.0\end{array}$ & $\begin{array}{c}8.8 \\
-10.9^{*} \\
1.5\end{array}$ & $\begin{array}{l}2.2 * \\
-1.1 \\
-2.7\end{array}$ \\
\hline ICGV 86564 & $\begin{array}{l}\text { Parental offect } \\
\text { Maternel effect } \\
\text { gce offect }\end{array}$ & $\begin{array}{l}8.1^{* *} \\
2.7 * \\
9.4^{* *}\end{array}$ & $\begin{array}{l}92.8^{* *} \\
13.4 \\
99.6^{* *}\end{array}$ & $\begin{array}{l}8.3^{* * *} \\
18.5^{* *} \\
16.8^{* * *}\end{array}$ & $\begin{array}{l}6.0^{* *} \\
2.2^{* *} \\
7.2^{* * *}\end{array}$ & $\begin{array}{l}44.8^{* * *} \\
5.5 \\
47.5^{* *}\end{array}$ & $\begin{array}{l}12.8 * * \\
2.7 \\
13.9 * *\end{array}$ & $\begin{array}{c}10.9^{* *} \\
4.7 \\
-8.5^{* *}\end{array}$ & $\begin{array}{c}-5.8 \\
15.6^{* *} \\
1.8\end{array}$ & $\begin{array}{l}1.0 \\
0.6 \\
1.3 * *\end{array}$ \\
\hline ICGV 87123 & $\begin{array}{l}\text { Perentel effect } \\
\text { Maternel offect } \\
\text { gce effect }\end{array}$ & $\begin{array}{r}0.0 \\
-0.9 \\
-0.4\end{array}$ & $\begin{array}{l}-37.8^{* *} \\
-17.4^{*} \\
-46.5^{* *}\end{array}$ & $\begin{array}{c}-21.3^{* *} \\
4.8 \\
-18.8 *\end{array}$ & $\begin{array}{l}1.1 \\
0.7 \\
1.4 * *\end{array}$ & $\begin{array}{l}-20.1 * * \\
-0.1 \\
-20.0 * *\end{array}$ & $\begin{array}{l}6.5^{* *} \\
1.7 \\
7.4^{* *}\end{array}$ & $\begin{array}{r}2.1 \\
-1.0 \\
1.6\end{array}$ & $\begin{array}{r}5.7 \\
-7.8 \\
1.7\end{array}$ & $\begin{array}{l}3.6^{* *} \\
2.7^{*} \\
4.8^{* *}\end{array}$ \\
\hline ICGV 86857 & $\begin{array}{l}\text { Perental offect } \\
\text { Meternal offect } \\
\text { gce offect }\end{array}$ & $\begin{array}{l}-0.3 \\
-1.0 \\
-0.8\end{array}$ & $\begin{array}{l}13.0 * \\
-\quad 6.7 \\
9.7 * *\end{array}$ & $\begin{array}{r}0.5 \\
-3.5 \\
-1.2\end{array}$ & $\begin{array}{r}0.1 \\
-0.7 \\
-0.2\end{array}$ & $\begin{array}{r}3.5 \\
-12.8 \\
-2.9\end{array}$ & $\begin{array}{c}4.7^{*} \\
-2.1 \\
3.8 *\end{array}$ & $\begin{array}{l}1.8 \\
8.6 \\
5.9^{* *}\end{array}$ & $\begin{array}{r}3.1 \\
-0.4 \\
2.8\end{array}$ & $\begin{array}{l}1.0 \\
0.4 \\
1.200\end{array}$ \\
\hline SE peret & intel [g] & 0.8 & 4.8 & 1.8 & 0.6 & 2.6 & 1.8 & 2.2 & 3.0 & 0.8 \\
\hline SE mate & irnel (m) & 0.8 & 6.9 & 2.7 & 0.9 & 3.7 & 2.5 & 3.1 & 4.3 & 1.1 \\
\hline $\begin{array}{l}\text { SE gce } \\
\text { SE gce }\end{array}$ & $\begin{array}{l}\text { Offects }\left[g_{1}\right) \\
\text { offects }\left[g_{1}-g_{J}\right)\end{array}$ & $\begin{array}{l}0.5 \\
0.7\end{array}$ & $\begin{array}{l}3.4 \\
5.2\end{array}$ & $\begin{array}{l}1.3 \\
2.0\end{array}$ & $\begin{array}{l}0.4 \\
0.7\end{array}$ & $\begin{array}{l}1.8 \\
2.8\end{array}$ & $\begin{array}{l}1.2 \\
1.8\end{array}$ & $\begin{array}{l}1.6 \\
2.4\end{array}$ & $\begin{array}{l}2.1 \\
3.2\end{array}$ & $\begin{array}{l}0.5 \\
0.8\end{array}$ \\
\hline
\end{tabular}

1 and 2 - refer as described in Table $1 .{ }^{*},{ }^{* *}$ - significant at 0.05 and 0.01 probability, respectively.

crosses was an indication of the fact that the parental lines involved in this study were genetically diverse. Further, significant differences in heterotic effects between straight and reciprocal crosses indicated the influence of cytoplasm and its interaction with nuclear genes in the manifestation of hybrid vigor. Heterosis for yield and its components in peanut was also reported by earlier workers $(2,3,4,7,11,18)$.

General combining ability effects were estimated to determine the breeding potential of each parent (Table 3). A breeding line, ICGV 86564, had the best gca for length, width, and weight of the seed and fruit. ICG 2379 and ICG 3043 had the best gca for fruit weight/ plant. ICGV 87123 had the best gca for shelling percentage. The best combiners for fruits/plant were ICG 4906 and ICGV 86857.

Character association among fruit and seed traits and with fruit yield per se were determined (Table 6). Fruit length and width and seed length and width were positively associated $(P=0.01)$ with each other and also with fruit and seed weight which revealed that selection for large fruit size should result in progenies with higher fruit and seed weight. Fruits/plant and fruit weight/ plant were positively associated $(P=0.01)$. Similar associations between fruit and seed size and number of fruits and fruit weight/plant were also reported from other studies $(6,12,14)$. The positive association between fruit weight/plant and fruits/plant, and of fruit weight/plant with all fruit and seed characters $(P=0.01)$, which was also reported by other workers $(5$, 13), indicated that selection for higher fruit weight or seed weight should lead to progenies with higher number of fruits and fruit yield. Fruits/plant on the other hand was negatively associated with all fruit and seed characters. Shelling percentage was negatively associated with fruit length $(\mathrm{P}=0.05)$ and width $(\mathrm{P}=0.01)$ and positively $(P=0.01)$ with seed weight and seed width indicating that selection of progenies with higher seed weight and width may improve the shelling percentage. However, it is difficult to explain why fruit width was negatively correlated with shelling percen- 
Table 4. Maternal interaction effects $\left(n_{i j}\right)$ for nine characters in $8 \times 88$ full diallel cross $F_{1}$ progenies in peanut.

\begin{tabular}{|c|c|c|c|c|c|c|c|c|c|}
\hline Crosses & $\begin{array}{l}\text { Fruit } \\
\text { weight }\end{array}$ & $\begin{array}{l}\text { Fruit } \\
\text { length }\end{array}$ & $\begin{array}{l}\text { Fruft } \\
\text { width }\end{array}$ & $\begin{array}{l}\text { Seed } \\
\text { weight }\end{array}$ & $\begin{array}{l}\text { Seed } \\
\text { long th }\end{array}$ & $\begin{array}{l}\text { Seed } \\
\text { width }\end{array}$ & $\begin{array}{l}\text { Fruite/ } \\
\text { plant }\end{array}$ & $\begin{array}{c}\text { Fruit } \\
\text { weight/plant }\end{array}$ & $\begin{array}{c}\text { Shalling } \\
{[x]}\end{array}$ \\
\hline ICG $7380 \times$ IC6 4908 & $11.09 * *$ & $71.18 * *$ & $34.64^{* *}$ & $8.05 * *$ & $28.33 * *$ & $37.18 * *$ & $28.08 * *$ & 9.89 & $7.69 * *$ \\
\hline IC6 $7380 \times$ ICB 2378 & 2.38 & $32.96 * *$ & $17.41 * *$ & -1.35 & $11.66^{*}$ & -0.14 & 9.52 & 2.49 & $-5.64 * *$ \\
\hline ICE $7380 \times$ IC6 3043 & -0.58 & $-84.71 * *$ & $17.71 * *$ & -2.32 & $-35.28 * *$ & $8.27 *$ & -7.85 & 10.38 & $-3.88^{*}$ \\
\hline ICE $7380 \times$ IC6 6150 & 1.12 & $29.31 * *$ & 5.58 & -0.62 & 1.87 & 0.35 & 8.64 & 7.39 & $-3,41^{*}$ \\
\hline ICE $7360 \times$ ICEV 68564 & -1.37 & $28.88^{* *}$ & -4.08 & -2.18 & 4.48 & -1.14 & -8.58 & -10.38 & -2.28 \\
\hline ICE $7360 \times$ ICOV 87123 & $9.88 * *$ & $101.89 * *$ & $-\mathbf{3 . 3 9}$ & 2.07 & $9.98^{*}$ & -0.48 & -0.91 & $11.89 *$ & $-8.26 * *$ \\
\hline ICE $7380 \times$ ICGV 88857 & 1.32 & $21.06 *$ & $15.10 *$ & -1.20 & $14.31 * *$ & -5.71 & $-35.80^{* 14}$ & 9.54 & $-4.71 * *$ \\
\hline ICG $4906 \times$ IC6 2379 & $-3.80 * *$ & $-19.04^{*}$ & $-14.89 *$ & $-2.70^{*}$ & -2.00 & $14.00^{* *}$ & $28.79^{* *}$ & 11.48 & 0.85 \\
\hline IC6 $4908 \times$ IC6 3049 & $-2.89 *$ & $-37.29 *$ & $-15.44^{* *}$ & -1.37 & $-20.85 * *$ & -4.41 & $33.98 * *$ & $21.490 *$ & 2.38 \\
\hline ICG $4906 \times$ ICG 6150 & -0.42 & -13.52 & $-8.38 *$ & 0.51 & -2.12 & 4.50 & $20.16^{* * *}$ & 9.71 & $3.55^{*}$ \\
\hline ICB $4908 \times$ ICOV 88584 & $-4.10 * *$ & $-28.18 * *$ & $-25.54 * *$ & $-2.58^{*}$ & $-11.54^{*}$ & -4.83 & $11.42^{*}$ & -1.77 & 1.53 \\
\hline ICG $4906 \times$ ICOV 87123 & -1.80 & -5.84 & $-11.71 * *$ & -1.75 & -8.52 & $-8.33^{*}$ & $24.62 * *$ & $19.82^{* * 4}$ & -0.58 \\
\hline ICG $4908 \times$ ICOV 88857 & -0.84 & -1.94 & $-10.37 * *$ & -0.54 & 2.14 & -4.38 & $18.00^{* *}$ & 10.80 & 0.18 \\
\hline IC6 $2379 \times$ IC6 3043 & -0.37 & -4.80 & -1.21 & -0.78 & -8.12 & 1.89 & -0.65 & 7.81 & -1.02 \\
\hline ICG $2378 \times$ ICG 6150 & -0.38 & $-20.48 * *$ & 2.00 & 0.80 & $-10.29 *$ & 4.50 & -1.64 & -5.80 & 2.36 \\
\hline ICO $2379 \times$ ICEV 88584 & 0.22 & $-40.88 *$ & $-58,98^{* *}$ & 0.70 & $-15.87 * *$ & $9.66 * *$ & -1.50 & -2.08 & 0.84 \\
\hline ICG $2978 \times$ ICGV 87123 & 0.88 & $30.27 * *$ & -4.81 & -0.25 & -0.88 & 0.83 & -1.78 & 5.98 & -2.08 \\
\hline ICG $2378 \times$ ICOV 88857 & $3.13^{*}$ & 11.27 & 1.18 & $2.64^{*}$ & 5.31 & $8.80 * *$ & -7.65 & 1.12 & 0.49 \\
\hline ICG $3043 \times$ ICG 6150 & -1.81 & 4.35 & 3.04 & -2.21 & $14.00 * *$ & $-12.41 * *$ & 4.54 & 10.41 & $-3.00 *$ \\
\hline ICE $3049 \times$ ICEV 86584 & -1.65 & 11.52 & $-8.77^{*}$ & -1.53 & $29.58 * *$ & -2.58 & -0.28 & $-13.39 *$ & -0.98 \\
\hline ICG $3043 \times$ ICEV 87123 & 0.28 & 8.44 & $-10,44^{* *}$ & -0.38 & 3,44 & -1.75 & $-15.54^{* *}$ & -11.18 & -1.38 \\
\hline IC6 $3043 \times$ ICEV 88857 & -1.02 & -0.39 & -0.77 & -1.05 & $27.27 * *$ & 0.52 & $-17.39 * *$ & $-13.85^{*}$ & -1.78 \\
\hline ICO $6150 \times$ ICGV 88584 & $-6.31 * *$ & $-21.33^{*}$ & $-9.81 *$ & $-5.9 \theta^{* *}$ & -7.82 & $-7.00 *$ & $-28.36 * *$ & $-49.81 * *$ & - 3.2e"* \\
\hline ICG $8150 \times$ ICEV 87123 & $-4.34 * *$ & -4.58 & -7.84 & $-5,90 * *$ & 3.27 & $-7.00^{\circ}$ & $-22.58 * *$ & -7.75 & $-8.700 \%$ \\
\hline IC6 $8150 \times$ ICGV 86857 & -0.78 & $-24.08^{*}$ & -3.64 & -0.17 & 2.77 & 3.80 & $-13.88 * *$ & -8.27 & 0.54 \\
\hline ICGV $88564 \times$ ICGV 87123 & $3.53^{* *}$ & 8.81 & $8.4 \theta^{*}$ & $2.46^{*}$ & 2.35 & 8.50 & 8.34 & $25.89 \%$ & 0.51 \\
\hline ICGV $88564 \times$ ICGV 86867 & $4.77 * *$ & $47.75^{* *}$ & $17.39 * *$ & $4.09 * *$ & $40.35 * *$ & $9.80^{* *}$ & 3.28 & $22.04 \%$ & 1.08 \\
\hline ICGV $87123 \times$ ICEV 88857 & 1.51 & 0.00 & $8.17 *$ & 1.70 & $10.83^{*}$ & 3.77 & $-18.17 *$ & $-17.85 * *$ & 0.89 \\
\hline $\operatorname{SE}\left(n_{1 j}\right)$ & 1.23 & \pm 9.07 & \pm 3.57 & \pm 1.18 & \pm 4.87 & \pm 3.27 & \pm 4.12 & \pm 5.59 & \pm 1.49 \\
\hline
\end{tabular}

1 and 2 - refer as described in Table 1. " ** - significant at 0.05 and 0.01 probability, respectively.

Table 5. Percent heterosis over better parent for nine characters in $8 \times 8$ full diallel cross $F_{1}$ progenies in peanut.

\begin{tabular}{|c|c|c|c|c|c|c|c|c|c|}
\hline Crosses & $\begin{array}{l}\text { Fruit } \\
\text { weight }\end{array}$ & $\begin{array}{l}\text { Fruit }{ }^{9} \\
\text { leng th }\end{array}$ & $\begin{array}{l}\text { Fruit }{ }^{9} \\
\text { width }\end{array}$ & $\begin{array}{l}\text { Seed } \\
\text { weight }\end{array}$ & $\begin{array}{l}\text { Seod }{ }^{2} \\
\text { length }\end{array}$ & $\begin{array}{l}\text { Seed } \\
\text { width }\end{array}$ & $\begin{array}{l}\text { Fruite } \\
\text { plent }\end{array}$ & $\begin{array}{c}\text { Fruit } \\
\text { weight/plant }\end{array}$ & $\begin{array}{c}\text { Sholling' } \\
{[x]}\end{array}$ \\
\hline ICG $7380 \times$ ICG 4908 & $-58.4 * *$ & $-22.7 * *$ & $-17.7^{* *}$ & $-67.6 *$ & $-24.7 * 4$ & $-38.00 \%$ & $62.4 * *$ & 7.1 & $-23.5 * *$ \\
\hline ICG $7360 \times$ ICG 2379 & -4.5 & -1.1 & $8.9 * 4$ & $-18.3^{* *}$ & 1.1 & $-11.00 \%$ & $50.7 *$ & $50.00 *$ & $-14,5 *$ \\
\hline ICG $7380 \times$ ICG 3043 & -0.4 & 0.7 & 2.8 & -0.2 & -1.1 & $-4.8^{* * *}$ & $70.7 * *$ & $45.8 *$ & $-3.80 \%$ \\
\hline ICG $7380 \times$ ICG 6150 & $-19.1 * *$ & $-3.8 * *$ & 0.0 & $-27.8 * *$ & -3.4 & $-10.6 *$ & 19.5 & 0.7 & $-12.5 * *$ \\
\hline ICE $7380 \times$ ICOV 68584 & $-17 \cdot 2^{* *}$ & $-12.5 * *$ & -1.8 & $-25.9 * *$ & $-14.7 * *$ & $-13,5 *$ & $77.1 *$ & 40.8 & $-10.8 * *$ \\
\hline ICG $7380 \times$ ICOV 87123 & 8.4 & $7.2^{* *}$ & -0.1 & 10.8 & 3.4 & 2.8 & 29.8 & 20.4 & 1.1 \\
\hline ICB $7380 \times$ ICGV 88857 & $17.7 * *$ & -2.8 & $6.7^{* *}$ & 5.1 & $5.2^{*}$ & $8.3^{* * *}$ & $220.4^{* *}$ & 28.5 & $-8.9 * *$ \\
\hline ICG $4906 \times$ ICG 7380 & -9.9 & -4.1 & $-4.1 * *$ & -8.5 & $-8.3 * *$ & $-5.5^{\circ}$ & -8.8 & -30.8 & 2.5 \\
\hline ICG $4908 \times$ ICG 2979 & $-47.4 * *$ & -20.20 & $-13.5^{* *}$ & $-60.1 *$ & $-21.8 * *$ & $-20.2^{n *}$ & 15.8 & -17.7 & $-5.2 *$ \\
\hline ICG $4908 \times$ IC6 3049 & $-49.4 *$ & $-29.7 * *$ & $-20.6 *$ & $-49.60 *$ & $-27.60 *$ & $-14.80 \%$ & 23.7 & -8.5 & $-4.5^{* *}$ \\
\hline ICB $4908 \times$ ICE 6150 & $-84.3 * *$ & $-33.2 * *$ & $-25.3 * *$ & $67.20 *$ & $-36.6 *$ & $-28.4 * *$ & $34.6^{*}$ & -31.4 & $-10.8 *$ \\
\hline ICG $4908 \times$ ICEV 88564 & $-62.6^{* * *}$ & $-30.9^{\circ * 4 *}$ & $-18.4 * *$ & $-64.6^{* * *}$ & $-29.7 * 4$ & $-25.800 \%$ & 18.8 & 28.1 & $-4.0^{\circ 0}$ \\
\hline ICG $4908 \times$ ICOV 87123 & $-38.8 * *$ & $-8.8 * *$ & $4.5^{*}$ & $-33.74 *$ & $-11.4^{* *}$ & $-14.00 \%$ & 99.7 & 29.7 & $6.1 * *$ \\
\hline
\end{tabular}

Continued on next page 


\begin{tabular}{|c|c|c|c|c|c|c|c|c|c|}
\hline Cros888 & $\begin{array}{l}\text { Fruft } \\
\text { wetght }\end{array}$ & $\begin{array}{l}\text { Frutt } \\
\text { length }\end{array}$ & $\begin{array}{l}\text { Fruit }{ }^{1} \\
\text { width }\end{array}$ & $\begin{array}{l}\text { Seod' } \\
\text { weight }\end{array}$ & $\begin{array}{l}\text { Seed } \\
\text { Leng th }\end{array}$ & $\begin{array}{l}\text { Seod } \\
\text { width }\end{array}$ & $\begin{array}{l}\text { Fruits/ } \\
\text { plent }\end{array}$ & $\begin{array}{c}\text { Fruft } \\
\text { weight/plent }\end{array}$ & $\begin{array}{c}\text { Shelling } \\
{[x]}\end{array}$ \\
\hline $\begin{array}{l}\text { ICG } 4908 \times \text { ICOV } 86857 \\
\text { ICG } 2379 \times \text { ICG } 7360\end{array}$ & $\begin{array}{c}-44.2 * * \\
0.84\end{array}$ & $\begin{array}{c}-29.1 * * \\
4.9 *\end{array}$ & $\begin{array}{l}-12.9 * * \\
15.1 * *\end{array}$ & $\begin{array}{l}-46.7 * * \\
-24.7 * *\end{array}$ & $\begin{array}{c}-18.7 * * \\
6.8 *\end{array}$ & $\begin{array}{l}-18.9 * * \\
-11.00 *\end{array}$ & $\begin{array}{l}14.8 \\
76.7 * *\end{array}$ & $\begin{array}{l}-9.2 \\
53.2 *\end{array}$ & $\begin{array}{l}-3.7 * 4 \\
-23.3 * 4\end{array}$ \\
\hline $\begin{array}{l}\text { ICG } 2379 \times \text { ICG } 4906 \\
\text { ICG } 2379 \times \text { IC6 } 9043 \\
\text { IC6 } 2379 \times \text { ICG } 8150 \\
\text { ICG } 2379 \times \text { ICGV } 86564 \\
\text { ICG } 2379 \times \text { ICEV } 87123\end{array}$ & $\begin{array}{c}-58.6^{*} \\
15.7^{* *} \\
3.4 \\
-1.23 \\
-12.3^{* *}\end{array}$ & $\begin{array}{l}-23.6 * * \\
-8.2^{* *} \\
-1.7 \\
-5.8 * * \\
-3.8\end{array}$ & $\begin{array}{c}-20.8^{* *} \\
3.5^{*} \\
0.0 \\
1.1 \\
-1.8\end{array}$ & $\begin{array}{c}-57.6^{* *} \\
14.8^{* *} \\
3.1 \\
-1.6 \\
-8.8^{*}\end{array}$ & $\begin{array}{l}-21.9^{* * *} \\
-8.7 * * \\
-8.5^{* * *} \\
-8.1 * * \\
1.6\end{array}$ & $\begin{array}{l}-28.7 * * \\
0.4 \\
-3.8 \\
-6.2 * * \\
-6.3 * *\end{array}$ & $\begin{array}{l}88.8 * * \\
114.7 * * \\
86.6 * * \\
12.3 \\
88.9 * *\end{array}$ & $\begin{array}{l}11.3 \\
89.7 * * \\
80.3 * * \\
25.8 \\
63.7 * *\end{array}$ & $\begin{array}{l}-2.4 \\
-0.7 \\
-8.1 * \\
-1.1 \\
\quad 3.7 * *\end{array}$ \\
\hline $\begin{array}{l}\text { ICG } 2379 \times \text { ICGV } 88857 \\
\text { ICG } 3043 \times \text { ICG } 7360 \\
\text { ICG } 3043 \times \text { ICG } 4808 \\
\text { ICG } 3043 \times \text { ICG } 2879 \\
\text { ICG } 3043 \times \text { ICG } 6150\end{array}$ & $\begin{array}{l}-9.5^{*} \\
-10.1^{* *} \\
-54.8^{* *} \\
12.4^{* *} \\
-7.1^{*}\end{array}$ & $\begin{array}{l}-7.8^{* * *} \\
-22.2^{* * *} \\
-34.0^{* * *} \\
-6.3^{* *} \\
3.7^{*}\end{array}$ & $\begin{array}{c}-2.2 \\
9.8^{* 1 *} \\
-28.2^{* *} \\
4.4^{* *} \\
-0.8\end{array}$ & $\begin{array}{l}-8.6^{*} \\
-17.6 * * \\
-52.2^{* *} \\
6.8 \\
-11.9 *\end{array}$ & $\begin{array}{l}-1.4 \\
-16.8 \% * \\
-31.7 \% * \\
-7.1 \% * \\
-7.4 \% *\end{array}$ & $\begin{array}{l}-7.5^{* *} \\
-0.3 \\
-18.6^{* * *} \\
1.3 \\
-5.1^{*}\end{array}$ & $\begin{array}{l}75.2^{* *} \\
14.7 \\
145.5^{* *} \\
104.0^{* *} \\
80.5^{* *}\end{array}$ & $\begin{array}{c}78.6 * * \\
70.3^{* *} \\
53.4^{* *} \\
112.8^{* *} \\
14.6\end{array}$ & $\begin{array}{c}0.6 \\
-12.000 \\
1.5 \\
-5.200 \\
-4.000\end{array}$ \\
\hline $\begin{array}{l}\text { ICG } 3043 \times \text { ICGV } 86584 \\
\text { ICG } 3043 \times \text { ICEV } 67123 \\
\text { ICG } 3043 \times \text { ICEV } 88857 \\
\text { ICG } 6150 \times \text { ICG } 7380 \\
\text { ICG } 6150 \times \text { ICG } 4908\end{array}$ & $\begin{array}{l}-21.8 * * \\
-15.2 * * \\
-12.4 * * \\
-23.2 * * \\
-62.1 * *\end{array}$ & $\begin{array}{l}-3.8^{*} \\
-15.0 * * \\
-5.4^{* *} \\
-0.17 \\
-84.6^{* *}\end{array}$ & $\begin{array}{l}-2.3 \\
-8.3 * * \\
-4.6^{* * *} \\
-0.6 \\
-27.2^{* * 4}\end{array}$ & $\begin{array}{l}-26.9^{* *} \\
-4.8 \\
-12.3^{*} \\
-36.5^{* *} \\
-61.7 * *\end{array}$ & $\begin{array}{l}-8.2^{* *} \\
-15.3^{* *} \\
-13.0^{* *} \\
-3.7^{*} \\
-34.6^{* *}\end{array}$ & $\begin{array}{l}-15.8^{* *} \\
-2.2 \\
-3.7 \\
-3.0^{* *} \\
21.4^{* *}\end{array}$ & $\begin{array}{r}69.8 * * \\
115.3^{* *} \\
87.1^{* *} \\
92.7 * * \\
59.4^{* *}\end{array}$ & $\begin{array}{c}118.1 * * \\
58.3^{* *} \\
85.6 * * \\
2.8 \\
-35.0\end{array}$ & $\begin{array}{l}-8.2^{* *} \\
8.3^{* 1 *} \\
-10.4 * * \\
-20.2^{* 1 *} \\
-2.1\end{array}$ \\
\hline $\begin{array}{l}\text { ICB } 6150 \times \text { ICB } 2379 \\
\text { ICG } 6150 \times \text { ICG } 3043 \\
\text { ICG } 6150 \times \text { ICGV } 88584 \\
\text { ICG } 6150 \times \text { ICGV } 87123 \\
\text { ICG } 6150 \times \text { ICGV } 88867\end{array}$ & $\begin{array}{l}-2.1 \\
-17.5^{* * *} \\
-2.1 \\
-13.5^{* *} \\
-13.1 * *\end{array}$ & $\begin{array}{l}-7.2 * \\
1.6 \\
-0.3 \\
-15.2^{* *} \\
-3.1\end{array}$ & $\begin{array}{c}2.7 \\
0.8 \\
0.8 \\
-13.1 * * \\
-5.7 * *\end{array}$ & $\begin{array}{l}1.7 \\
-28.7 * * \\
-6.8 \\
-1.4 \\
-12.4 * *\end{array}$ & $\begin{array}{l}-12.6 * * \\
-4.8 * * \\
-0.4 \\
-18.3 * * \\
-12.9^{* *}\end{array}$ & $\begin{array}{l}-2.4 \\
-16.2 * * \\
-8.1 * * \\
1.6 \\
-2.1\end{array}$ & $\begin{array}{c}50.0^{*} \\
93.8^{* *} \\
117.1^{* *} \\
109.5^{* *} \\
53.8^{* *}\end{array}$ & $\begin{array}{l}39.6 * \\
54.7 * * \\
124.0 * * \\
58.4 * * \\
22.6\end{array}$ & $\begin{array}{l}-4.9 * * \\
-14.0 * * \\
-4.9 * * \\
-8.3^{* *} \\
-8.2 * *\end{array}$ \\
\hline $\begin{array}{l}\text { ICGV } 86564 \times \text { ICG } 7360 \\
\text { ICGV } 88584 \times \text { ICG } 4808 \\
\text { ICOV } 86584 \times \text { ICG } 2979 \\
\text { ICGV } 86564 \times \text { ICG } 3043 \\
\text { ICBV } 86584 \times \text { ICG } 6150\end{array}$ & $\begin{array}{l}-22.5 * * \\
-68.8 * * \\
3.2 \\
-22.9 * * \\
-17.4 * *\end{array}$ & $\begin{array}{l}-6.8 * * \\
-33.7 * * \\
-13.6 * * \\
-1.6 \\
-3.1 *\end{array}$ & $\begin{array}{l}-2.2 \\
-25.00 \% \\
-25.0 * * \\
-2.5 \\
0.7\end{array}$ & $\begin{array}{l}-31.8 * * \\
-58.7 * * \\
5.1 \\
-30.8 * * \\
-28.8 * *\end{array}$ & $\begin{array}{l}-12.3^{* *} \\
-31.8 * * \\
-13.3^{* * *} \\
3.4^{*} \\
-1.8\end{array}$ & $\begin{array}{l}-15.4 * * \\
-25.2 * * \\
1.1 \\
-15.7 * * \\
-12.5 * *\end{array}$ & $\begin{array}{c}79.2^{*} \\
41.6^{*} \\
41.1 \\
113.3^{* *} \\
-37.8\end{array}$ & $\begin{array}{c}17.3 \\
32.8 \\
55.6 * \\
100.3^{*} \\
-35.8^{*}\end{array}$ & $\begin{array}{c}-12.5^{* *} \\
0.14 \\
1.0 \\
-10.3^{* *} \\
-11.4 * *\end{array}$ \\
\hline $\begin{array}{l}\text { ICOV } 88564 \times \text { ICOV } 87123 \\
\text { ICOV } 88584 \times \text { ICOV } 88857 \\
\text { ICOV } 87123 \times \text { ICG } 7380 \\
\text { ICGV } 87123 \times \text { ICG } 4908 \\
\text { ICOV } 87123 \times \text { ICG } 2378\end{array}$ & $\begin{array}{l}-9.1 * * \\
-28.2 * * \\
57.4 * * \\
-49.0 * * \\
-11.7 * *\end{array}$ & $\begin{array}{c}-13.3^{* *} \\
-8.5^{* *} \\
38.9^{* *} \\
-11.4^{* *} \\
4.2^{*}\end{array}$ & $\begin{array}{l}-10.3^{* *} \\
-8.2^{* *} \\
-3.8 * * \\
3.1 \\
-0.8\end{array}$ & $\begin{array}{l}-2.3 \\
-38.5 * * \\
30.8 * * \\
-37.1 * * \\
-11.1 *\end{array}$ & $\begin{array}{r}-15.1 * * \\
-14.8 * * \\
9.2 * * \\
-14.4 * * \\
2.6\end{array}$ & $\begin{array}{l}-2.8 \\
-14.5^{* *} \\
0.8 \\
-17.2^{* *} \\
-8.0 *\end{array}$ & $\begin{array}{c}21.4 \\
9.7 \\
42.8 * \\
194.8 * * \\
80.5 * *\end{array}$ & $\begin{array}{l}72.8 * * \\
21.1 \\
61.2 * * \\
107.8 * * \\
75.8^{* *}\end{array}$ & $\begin{array}{c}7.4 * * \\
-12.5^{* *} \\
-17.7 * * \\
10.3^{* *} \\
0.7\end{array}$ \\
\hline $\begin{array}{l}\text { ICGV } 87123 \times \text { ICB } 3043 \\
\text { ICOV } 87123 \times \text { ICG } 6150 \\
\text { ICGV } 87123 \times \text { ICGV } 86564 \\
\text { ICGV } 87123 \times \text { ICGV } 88857 \\
\text { ICGV } 88857 \times \text { ICE } 7380\end{array}$ & $\begin{array}{l}-15.8 * * \\
-30.8 * * \\
-2.8 \\
2.5 \\
13.9 *\end{array}$ & $\begin{array}{l}-17.5 * * \\
-17.9 * * \\
-14.8 * * \\
-10.2 * * \\
-1.2\end{array}$ & $\begin{array}{c}-12.5 * * \\
-15.4 * * \\
-8.7 * * \\
0.5 \\
11.8 * *\end{array}$ & $\begin{array}{c}-4.8 \\
-39.8 * 4 \\
5.7 \\
7.2 \\
-7.8\end{array}$ & $\begin{array}{l}-18.1 * * \\
-18.5^{* *} \\
-15.2^{* *} \\
-5.0 * \\
8.0 * *\end{array}$ & $\begin{array}{r}-1.7 \\
-3.8 \\
2.6 \\
0.8 \\
-0.8\end{array}$ & $\begin{array}{c}29.8 \\
-11.8 \\
60.7 * * \\
125.8 * * \\
48.2\end{array}$ & $\begin{array}{c}4.2 \\
31.4 \\
185.2^{* * *} \\
144.9 * * \\
72.5^{* *}\end{array}$ & $\begin{array}{r}7.1 * * \\
-4.5^{* *} \\
8.8 * * \\
5.1 * * \\
-18.6 * *\end{array}$ \\
\hline $\begin{array}{l}\text { ICGV } 88857 \times \text { ICG } 4808 \\
\text { ICGV } 86857 \times \text { ICG } 2378 \\
\text { ICEV } 86857 \times \text { ICG } 3043 \\
\text { ICGV } 86857 \times \text { ICG } 8150 \\
\text { ICGV } 86857 \times \text { ICGV } 88564\end{array}$ & $\begin{array}{l}-43.8 * * \\
0.8 \\
-18.2 * * \\
-15.8 * * \\
-18.8 *\end{array}$ & $\begin{array}{l}-27.3^{* *} \\
-4.5^{*} \\
-8.8^{* *} \\
-9.5^{* *} \\
-0.3\end{array}$ & $\begin{array}{l}-16.0 * * \\
0.0 \\
-5.4 * * \\
-8.1 * * \\
-4.0 * *\end{array}$ & $\begin{array}{c}-45.0^{* *} \\
2.8 \\
-21.8^{* *} \\
-11.5^{*} \\
-25.8^{* *}\end{array}$ & $\begin{array}{c}-18.5 * \\
-0.5 \\
-8.5 * \\
-14.8^{*} \\
0.41\end{array}$ & $\begin{array}{l}17.7 * * \\
-2.1 \\
-2.8 \\
-0.8 \\
-8.3 * *\end{array}$ & $\begin{array}{l}87.9 * * \\
72.0 * * \\
25.8 \\
39.2 \\
44.1\end{array}$ & $\begin{array}{c}20.2 \\
89.1 * \\
35.8 \\
9.5 \\
88.2 \%\end{array}$ & $\begin{array}{c}-2.7 \\
1.5 \\
-13.8 * \\
-4.7 * 4 \\
-8.8 * 4\end{array}$ \\
\hline ICGV $88857 \times$ ICGV 87123 & $10.7 *$ & $-8.6 * *$ & $3,8 *$ & $15.0 \% *$ & -2.11 & 2.7 & $52.7 * *$ & $87.0 \%$ & $4.5 * *$ \\
\hline
\end{tabular}

1 and 2 - refer as described in Table 1. ", "* - significant at 0.05 and 0.01 probability, respectively.

tage when seed width was positively associated with it and with the fruit width.

The present study and those reported earlier indicated considerable genetic variation for most of the fruit and seed characters. The largely additive genetic effects for fruit and seed characters and a positive association among these traits and with seed weight suggest that selection for large fruit and higher seed weight should be effective in early generation. Selection for higher fruit weight and fruit number per plant may not be effective in early generation due to the predominantly nonadditive genetic effects and should be deferred to later generations. In the present material, maternal effects and their interaction with genic effects were also 
Table 6. Genotypic (below diagonal) and phenotypic (above diagonal) correlations among nine characters in $8 \times 8$ full diallel cross $F_{1}$ progenies in peanut.

\begin{tabular}{|c|c|c|c|c|c|c|c|c|c|}
\hline Charecter & $\begin{array}{l}\text { Fruit } \\
\text { weight }\end{array}$ & $\begin{array}{l}\text { Frutt } \\
\text { length }\end{array}$ & $\begin{array}{l}\text { Fruit } \\
\text { width }\end{array}$ & $\begin{array}{l}\text { Seed } \\
\text { weight }\end{array}$ & $\begin{array}{l}\text { Seed }{ }^{2} \\
\text { length }\end{array}$ & $\begin{array}{l}\text { Seed } \\
\text { width }\end{array}$ & $\begin{array}{l}\text { Fruits } \\
\text { plant }\end{array}$ & $\begin{array}{c}\text { Fruit } \\
\text { weight/plant }\end{array}$ & $\begin{array}{c}\text { Shelling } \\
{[x]}\end{array}$ \\
\hline Fruit weight & - & $0.82 *$ & $0.75^{* *}$ & $0.95 * *$ & $0.79 * *$ & 0.8800 & -0.18 & $0.46 \%$ & 0.09 \\
\hline Fruit length & 0.88 & - & $0.78 * *$ & $0.79 * *$ & $0.95 * *$ & $0.59 * *$ & -1.15 & $0.40 * *$ & $-0.18 *$ \\
\hline Fruit width & 0.78 & 0.78 & - & $0.69 * *$ & $0.74 * *$ & $0.57 * *$ & -0.18 & $0.36 * *$ & $-0.32 *$ \\
\hline Seed weight & 0.98 & 0.78 & 0.65 & - & $0.88 * *$ & $0.92 \%$ & -0.14 & $0.45 * *$ & $0.37 * *$ \\
\hline Seed length & 0.83 & 0.88 & 0.77 & 0.74 & - & $0.60 * *$ & $-0.17 *$ & $0.39 * *$ & $-0.15 * *$ \\
\hline Seed width & 0.91 & 0.67 & 0.84 & 0.95 & 0.64 & - & -0.16 & $0.45^{* *}$ & $0.37^{* * 4}$ \\
\hline Fruit\&/plent & -0.29 & -0.20 & -0.22 & -0.24 & -0.24 & -0.25 & - & $0.62 * *$ & 0.09 \\
\hline $\begin{array}{l}\text { Frult woight/ } \\
\text { plent }\end{array}$ & 0.60 & 0.55 & 0.50 & 0.62 & 0.59 & 0.54 & 0.33 & - & 0.07 \\
\hline $\begin{array}{c}\text { Shelling } \\
(\%)\end{array}$ & 0.01 & -0.20 & -0.37 & 0.27 & -0.29 & 0.32 & 0.13 & 0.15 & - \\
\hline
\end{tabular}

1 and 2 - refer as described in Table $1 .{ }^{*},{ }^{* *}$ - significant at 0.05 and 0.01 probability, respectively.

important in several crosses. Among the genotypes studied, ICGV 86564, ICG 3043, ICG 2379, and ICGV 87123 have good breeding potential, and populations derived between these genotypes should result in superior progenies with desirable traits. Crosses with the higher heterotic effects may produce desirable transgressive segregants in later generations.

\section{Literature Cited}

1. Al-Jibouri, H. A., P. A. Miller and H. F. Robinson. 1958. Genotypic and environmental variances and covariances in an upland cotton cross of interspecific origin. Agron. J. 50:633-636.

2. Arunachalam, V., A. Bandyopadhyay, S. N. Nigam and R. W. Gibbons. 1982. Heterotic potential of single crosses in groundnut (Arachis hypogaea L.). Oleagineux 37:415-418.

3. Arunachalam, V., A. Bandyopadhyay, S. N. Nigam and R. W. Gibbons. 1984. Heterosis in relation to genetic divergence and specific combining ability in groundnut (Arachis hypogaea L.). Euphytica 33:33-39.

4. Arunachalam, V., A. Bandyopadhyay and M. V. Koteswara Rao. 1985. Performance of three-way crosses in groundnut. Indian J. Agrl. Sci. 55:75-81.

5. Chiow, H. Y. and J. C. Wynne. 1983. Heritabilities and genetic correlations for yield and quality traits of advanced generations in a cross of peanut. Peanut Sci. 10:13-17.

6. Coffelt, T. A. and R. O. Hammons. 1974. Correlations and heritability studies of nine characters in parental and infraspecific-cross populations of Arachis hypogaea. Oleagineux 29:2327.

7. Garet, B. 1976. Heterosis and combining abilities in groundnut (Arachis hypogaea L.). Oleagineux 31:435-442.

8. Godoy, I. J. D. and A. J. Norden. 1981. Shell and seed size relationship in peanuts. Peanut Sci. 8:21-24

9. Green, C. C., J. C. Wynne and M. K. Beute. 1983. Genetic vari- ability and heritability estimates based on $F_{2}$ generation from crosses of large-seeded virginia-type peanuts with lines resistant to Cylindrocladium Black Rot. Peanut Sci. 10:47-51.

10. Griffing, B. 1956. Concept of general and specific combing ability in relation to diallel crossing systems. Austr. J. Biol. Sci. 9:463493.

11. Isleib, T. G. and J. C. Wynne. 1983. Heterosis in testcrosses of 27 exotic peanut cultivars. Crop Sci. 23:832-841.

12. Layrisse, A., J. C. Wynne and T. G. Isleib. 1980. Combining ability for yield, protein and oil of peanut lines from South American Centers of diversity. Euphytica 29:561-570.

13. Mohammed, J., J. C. Wynne and J. O. Rawlings. 1978. Early generation variability and heritability estimates in crosses of virginia and spanish peanuts. Oleagineux 33:81-86.

14. Nigam, S. N., S. L. Dwivedi, T. S. N. Sigamani and R. W. Gibbons. 1984. Character association among vegetative and reproductive traits in advanced generation of intersubspecific and intrasubspecific crosses in peanut. Peanut Sci. 11:95-98.

15. Sandhu, B. S. and A. S. Khera. 1976. The role of epistasis in the inheritance of yield and its components in groundnut. Crop Improvement 3:9-17.

16. Sangha, A. S. and K. S. Labana. 1982. Diallel analysis in groundnut (Arachis hypogaea L.) Part II. Pod number and pod yield. Theor. Appl. Genet. 64:59-63.

17. Singh, M. and K. S. Labana. 1980. Combining ability in groundnut. Crop Improvement. 7:123-128.

18. Swe, S. T. and W. D. Branch. 1986. Estimates of combining ability and heterosis among peanut cultivars. Peanut Sci. 13:70-74.

19. Topham, P. B. 1966. Diallel analysis involving maternal and maternal interaction effects. Heredity 21:665-674.

20. Wynne, J. C., D. A. Emery and P. W. Rice. 1970. Combining ability estimates in Arachis hypogaea L. II. Field performance of $F_{1}$ hybrids. Crop Sci. 10:713-715.

21. Wynne, J. C., J. O. Rawlings and D. A. Emery. 1975. Combining ability estimates in Arachis hypogaea L. III. $\mathrm{F}_{2}$ generations of intra- and inter-subspecific crosses. Peanut Sci. 2:50-54.

Accepted April 18, 1989 